\title{
Genotype and environmental interaction in cowpea (Vigna Unguiculata-L) for yield and disease resistance
}

\author{
"Y. Ali, Z. Aslam, F. Hussain and A. Shakur \\ Nuclear Institute of Agriculture and Biology, P. O. Box 128, Faisalabad, Pakistan
}

\begin{abstract}
Absract
Twenty-six cowpea cultivars were tested for yellow mosaic virus resistance at NIAB Faisalabad. NCPM-1, Elite, IT-84-552, No.44, P-518, S.A. Dandy, IT-97k-350-4, IT-93K-452, IT-97K-1042-8 and IT-97K-497-2 showed resistant reaction to yellow mosaic virus disease. As the study was aimed to select disease resistant and high yielding cultivars. Five cultivars viz. NCPM-1, Elite. S.A. Dandy, IT-97K-497-2 and IT-97K-1042-8 were chosen and evaluated at five different ecological zones during the year 2003. At each location, the experiment was laid out in a randomized complete block design keeping $7.2 \mathrm{~m}^{2}$ plot size in three repeats. At maturity the seed yield was collected and subjected to analysis of variance following stability parameters, varieties, environment and varieties x environment showed significant differences. Significant and highest seed yield (880 $\mathrm{kg} / \mathrm{ha}$ ) was observed in NIAB cowpea mutant-1 followed by Elite $(729 \mathrm{Kg} / \mathrm{ha})$. The highest yielding genotypes i.e. NIAB cowpea Mutant-1 and Elite showed non-significant differences of regression coefficient from one. Moreover these genotypes also exhibited non-significant difference of standard deviation to regression from zero. Based on three parameters i.e. high mean seed yield, regression coefficient and standard deviation to regression, these genotypes showed excellent and trustworthy stable performance over different environment. Hopefully these genotypes will definitely be helpful for increasing one local production of cowpea crop.
\end{abstract}

Key words: Cowpea, yield, yellow mosaic virus, genotypes, stability

* Corresponding Author, E-mail: yousaf_sem@yahoo.com

\section{Introduction}

The cowpea (Vigna unguiculata. L.) commonly known, as Lobia is an annual legume. This important tropical and subtropical legume is grown for forage green pods and grains. It is an excellent source of protein. White seeded varieties and black-eyed types are commonly grown for grain and table use. While viny varieties that mature late are preferred for forage cowpea and can be grown on wide range of soil types and under a diversity of climatic and cultural condition. Highest yields of forage are obtained in sandy loam soils supplemented with proper irrigation. However for seed purpose, cowpea reasonably performs well on soil with low fertility. High rates of nitrogen and excessive moisture are detrimental and can result in excessive vegetative growth, delayed maturity and pod shattering. In Pakistan cowpea is grown on an area of approximately 17 Thousand hectares with annual production of 8 thousand tones (Anonymous, 2001). This poor yield may be due to unavailability of high yielding and stable genotypes along with appropriate advance agronomic management practices. To bridge the yield gap and widen the genetic base, both mutation and other related breeding techniques were employed. Several genotypes with high seed yield potential and altered plant type like early maturity, reduced plant height and upright growth habit, were identified and evaluated in station and then in adaptation trials to study seed yield stability in different ecological zones of Punjab Province.The yielding ability of a genotype is the ultimate result of favorable interaction of genotype with the environment. Environmental factors such as moisture content, time of sowing, air temperature and photo-period length, soil characteristics and soil fertility differ across years and locations having significant influence at different developmental stages of crop growth (Bull, et al., 1992). Specific response of a genotype may be observed in a particular environment and its stable performance over different environment is a 
desirable characteristics. Which depends upon the magnitude of genotype $\mathrm{x}$ environment interaction (Ahmed, et al., 1996) a genotype is considered to have agronomically stability if it yields well with respect to the productive potential of the test environment (Romagosa, et al., 1996)? Stable genotypes are defined as the cultivar that makes the smallest contribution to the genotypes $\mathrm{x}$ environment interaction $(\mathrm{G} \times \mathrm{E})$. (Eberhert and Russell, 1996), model had been widely used to study stability parameters through genotypes $\mathrm{X}$ environment interaction i.e. mean seed yield, regression coefficient and deviation from regression.

The present research work deals with the determination of disease resistance, seed yielding ability, magnitude and nature of genotype $\mathrm{x}$ environment interaction and stability characteristics of newly evolved cowpea genotypes, tested under different environmental conditions.

\section{Materials and Methods}

Cowpea varieties were evaluated during the post-rainy season after maize at NIAB farm in Faisalabad during the last week of August 2003 (Table 1). Due to the shortage of seed each cultivar was planted only in 4 rows of 5 meters long. Cultivars were planted at $15 \mathrm{~cm}$ plant-to-plant $30 \mathrm{~cm}$ row-to-row distance using cowpea-2000 a highly susceptible variety to yellow mosaic virus disease as a spreader after each cultivar. Fertilizer at the rate of 20: 20: $20 \mathrm{Kg}$ ha- $\mathrm{N}_{2}$, $\mathrm{P}_{2} \mathrm{O}_{5}$ and $\mathrm{K}_{2} \mathrm{O}$ were applied before planting. Scoring of yellow mosaic virus (YMV) was recorded as mentioned by Malik, et al., (1986) on 4-5 week old plants.

\section{$\underline{\text { Yellow Mosaic Virus Disease Severity Scale }}$}

\section{Plant reaction /symptoms}

Scale

1. No visible symptoms; plant normal;

Immune

2. Very small yellow chlorotic spots; very few in number, scattered over younger leaves only covering up to $5 \%$ of the leaf area; plant growth, Flowering and pod formation normal; Highly resistant

3. Small chlorotic flecks, few in number, not coalescing and scattered over lamina of younger leaves covering $6-10 \%$ of the leaf area, plant growth flowering and pod formation normal;

\section{Resistant}

4. Yellow chlorotic flecks, larger in size overing $11-30 \%$ of the leaf area, irregular margins often coalescing and forming a patch, plant growth, flowering and pod formation slightly affected;

Tolerant

5. Yellow chlorotic flecks, larger in size covering $30-40 \%$ of the leaf area, irregular margins often coalescing and forming a patch, plant growth and pod formation affected; plant tend to recover later on;

Moderately tolerant

6. Yellow mottle covering about $50 \%$ of the leaf area, flecks coalescing and forming irregular patches; flowering and pod formation markedly reduced; Disease symptoms persist;

Moderately susceptible

7. Recently developed necrotic mottled flecks covering $51-70 \%$ of the leaf area; leaves and branches turning yellow; marked reduction in leaf size; plant growth stunted; severe reduction or no flowers and pod formation; pods if formed are yellow; curved and smaller containing fewer shriveled grains;

Susceptible

8. Young leaves turning yellow; severe stunting of plant highly susceptible growth and reduction in leaf size; whole plant body turning yellow often leading to death of the plant at early stages of growth, Flowering and pod formation negligible;

Highly susceptible

Four cultivars viz. Elite, S. A. Dandy, IT97K-497-2 and IT-97K-1042-8 resistant to yellow mosaic virus disease along with NIAB cowpea mutant-1 (NCPM-1) evolved through nuclear techniques using gamma radiation Co60 source and selected in $\mathrm{m} 2$ generation from 25KR dose now (M-5 generation) were tested at five different locations during the year 2003. Experiment was laid out in the province of Punjab in Faisalabad, Toba Tek 
Singh and Jhang districts. Each genotype was planted in three repeats in (RCBD) having plot size of $7.2 \mathrm{~m} 2$. At the time of maturity the seed yield data was collected and subjected to analysis of variance (Steel and Torrie, 1980) and stability parameters following Eberhart and Russel Model (1966)

\section{Results}

It is evident from the data that cowpea genotypes under study vary in reaction to yellow mosaic virus disease (Table 1). Genotypes NCPM-1, IT-84-552, No 44, Elite, P-518 and S.A Dandy showed highly resistant to resistant reaction IT-95K-1156-3, IT-94K137-6, IT-97K-1042-8 and IT-97K-499-4 showed tolerant reaction to yellow mosaic virus disease. Spreader cowpea-2000 showed highly susceptible reaction. All other entries tested exhibited moderately susceptible to susceptible reaction. Yellow mosaic virus (YMV) is a serious disease of cowpea in summer crop season and inflicts heavy yield losses when its attack is severe. YMV is transmitted by the vector cotton fly (Bemmesia tobacco Gene). The symptoms on 2-3 weeks old seedling stat appearing as yellow specks or spots on the young leavers. The new leaves emerging from the apex show bright yellow patches interspersed with green areas. The size of yellow areas increase in the new growth and in several cases there is a complete yellowing of the leaves. In tolerant varieties the diseased plants usually tend to recover later on depending on the environmental conditions but their pod bearing ability may be adversely affected if the diseases become sever and prolonged. In susceptible varieties the diseased plants remain stunted, turn completely yellow and usually die out at the early stage of their growth. Analysis of variance (Table 2) showed that varieties environment and varieties $\mathrm{x}$ environment interaction had significant differences. The significant differences in the genotypes under study may be used due to variation in their genetic make up and significant differences in the environments are indication of diverse type of environment of different locations/ seasons. The significant differences among the varieties $\mathrm{x}$ environment interaction may be of cross over nature or noncross over nature. In cross over nature, the significant change in ranks occurs from one environment to another and in non cross over
Table 1: Yellow mosaic virus disease infection in cowpea cultivars

\begin{tabular}{|clc|}
\hline Sr. \# & \multicolumn{1}{|c|}{ Variety Name } & $\begin{array}{c}\text { Yellow Mosaic } \\
\text { Virus Percent }\end{array}$ \\
\hline 1 & 1T-97k-461-4 & 70 \\
\hline 2 & $1 T-98 k-469-11$ & 63 \\
\hline 3 & $1 T-97 k-1068-7$ & 70 \\
\hline 4 & $1 T-94 k-440-3$ & 53 \\
\hline 5 & $1 T-95 k-627-34$ & 56 \\
\hline 6 & 1T-95k-1093-5 & 63 \\
\hline 7 & 1T-97k-1021-15 & 70 \\
\hline 8 & Lobia-2000 & 80 \\
\hline 9 & 1Tk-238-3 & 80 \\
\hline 10 & 1T-98k-463-6 & 63 \\
\hline 11 & 1T-97k-529-14 & 63 \\
\hline 12 & 1T-98k-558-1 & 70 \\
\hline 13 & 1T-95k-1156-3 & 23 \\
\hline 14 & 1T-94k-137-6 & 20 \\
\hline 15 & 1T-97k-1042-8 & 16 \\
\hline 16 & 1T-97k-499-4 & 20 \\
\hline 17 & 1T-97k-497-2 & 10 \\
\hline 18 & 1T-93k-452 & 10 \\
\hline 19 & 1T-97k-350-4 & 10 \\
\hline 20 & S.A Dandy & 10 \\
\hline 21 & P-518 & 10 \\
\hline 22 & Elite & 15 \\
\hline 23 & No-44 & 15 \\
\hline 24 & It-84-552 & 7 \\
\hline 25 & NIAB-Cowpea- & 5 \\
\hline 26 & Mutant-1 (NCPM-1) & 85 \\
\hline & & \\
\hline
\end{tabular}

the ranking of genotypes remains constant across environments and the interaction is significant due to change in the magnitude of response (Matus, et al., 1997). In the present study the interaction was of cross over nature. Overall Mean Seed yield $(\mathrm{kg} / \mathrm{ha})$ of all 5 locations showed significant differences (Table 3 and 4). The highest seed yield (880 kg/ha) was achieved by genotype NIAB cowpea Mutant- 1 followed by Elite $(729 \mathrm{Kg} / \mathrm{ha})$ as compared to $666 \mathrm{Kg} / \mathrm{ha}$ of grand total mean. The regression co-efficient of these genotypes ranged from 0.501 to 1.557 , which was not significant by difference from unity. The maximum value (1.557of regression coefficient (bi) was shown by NIAB cowpea Mutant-1 followed by Elite (1.100). High mean seed yield combined with high value of regression coefficient (bi) indicated its response to the favourable conditions (Eberhert and Russel, 1966). 
Table 2: Pooled analysis of variance for cowpea

\begin{tabular}{|lcccc|}
\hline \multicolumn{1}{|c}{ Source } & Df & S.S & M.S & F. Value \\
\hline Total & 24 & 0.507 & 0.021 & \\
\hline Environments & 4 & 0.054 & 0.013 & \\
\hline Varieties & 4 & 0.440 & 0.110 & $228.534^{* *}$ \\
\hline Varieties x Environment & 16 & 0.014 & 0.000 & \\
\hline Environment + Varieties x Environment & 20 & 0.067 & 0.003 & \\
\hline Environment (Line) & 1 & 0.054 & 0.054 & \\
\hline Varieties x Environment (Line) & 4 & 0.006 & 0.002 & $3.287 *$ \\
\hline Pooled Deviation & 15 & 0.007 & 0.000 & $1.002 \mathrm{NS}$ \\
\hline Pooled Error & 50 & 0.024 & 0.000 & \\
\hline
\end{tabular}

Table 3: Performance of different disease resistant cowpea lines in multilocational yield trials

\begin{tabular}{|c|c|c|c|c|c|}
\hline Sr. \# & Genotype & $\begin{array}{c}\text { Mean Seed Yield } \\
\text { Ton/ha }\end{array}$ & $\begin{array}{l}\text { Regression Co- } \\
\text { efficient (bi) }\end{array}$ & \multicolumn{2}{|c|}{$\begin{array}{l}\text { Standard deviation to } \\
\text { regression }\left(\mathrm{Sd}^{2}\right)\end{array}$} \\
\hline 1 & NCPM-1 & 0.880. A & $1.557 *$ & 0.000 & \multirow{6}{*}{$\begin{array}{l}\text { NS From } \\
\text { zero }\end{array}$} \\
\hline 2 & Elite & $0.729 . \mathrm{B}$ & $1.100 \mathrm{NS}$ & 0.000 & \\
\hline 3 & S.A. Dandy & $0.658, \mathrm{C}$ & $0.982 \mathrm{NS}$ & 0.001 & \\
\hline 4 & IT-97k-497-2 & $0.569 . \mathrm{D}$ & $0.861 \mathrm{NS}$ & 0.000 & \\
\hline 5 & IT-97K-1042-8 & $0.496 . \mathrm{E}$ & $0.501 *$ & 0.000 & \\
\hline & Mean & 0.6664 & & & \\
\hline
\end{tabular}

Table 4: Performance of cowpea genotypes in multilocational yield Trials during the year 2002-03 (Kg/ha)

\begin{tabular}{|lccccc|}
\hline Genotype & 1 & 2 & 3 & 4 & 5 \\
\hline NCPM-1 & $\mathrm{s}$ & $925 \mathrm{~A}$ & $852 \mathrm{~A}$ & $831 \mathrm{~A}$ & $793 \mathrm{~A}$ \\
\hline Elite & $833 \mathrm{~B}$ & $730 \mathrm{~B}$ & $708 \mathrm{~B}$ & $694 \mathrm{~B}$ & $678 \mathrm{~B}$ \\
\hline S.A. Dandy & $703 \mathrm{C}$ & $700 \mathrm{C}$ & $654 \mathrm{C}$ & $674 \mathrm{C}$ & $559 \mathrm{C}$ \\
\hline IT-97k-497-2 & $624 \mathrm{D}$ & $608 \mathrm{D}$ & $557 \mathrm{D}$ & $540 \mathrm{D}$ & $515 \mathrm{D}$ \\
\hline IT-97K-1042-8 & $535 \mathrm{E}$ & $506 \mathrm{E}$ & $472 \mathrm{E}$ & $503 \mathrm{E}$ & $465 \mathrm{E}$ \\
\hline
\end{tabular}

\section{Detail of Locations}

1. Ch. Muhammad Iqbal Chak \# 63 /J.B Gillan wali Faisalabad

2. Ch. Babar Chak\# 91/ J.B Teh. Gojra Distt. Toba Tek Singh

3. Mahar Charagh Khan Chak 498/ J.B Shorkot Jhang

4. Ch. Rehmat ullah Moza Allah Yaar Juta Shorkot Jhang

5. Muhammad Saleem Chak \# 492/J.B Shorkot Jhang. 


\section{Discussion and Conclusion}

Accordingly, a stable genotype is the one for which the regression coefficient did not show any significant difference from one and thus stability is defined as the consistency in performance of a variety over varying environments.

According 2 values around unity (1) means less responsive to environmental changes, and hence showing more adaptive ness to all types of environments.

Thus a genotype with unit regression coefficient, and the deviation to regression not significant different from zero is said to be the stable one. In the present research work genotype NCPM-1 and Elite had regression coefficient almost close to unity and similarly also showed deviation to regression closer to zero. Their mean seed yield also secured $1^{\text {st }}$ and $2^{\text {nd }}$ position, Hence these genotypes may be regarded as most stable genotypes as compared to others.

Due to its great flexibility to fit in different crop rotation and intercropping pattern, cowpea is likely to contribute significantly in boosting up the pulse production in the country.

\section{References}

Ahmad, J., M. H. Choudhery, S. Salah-ud Din and M. A. Ali, Stability for grain yield in wheat. Pak.J.Bot., 28: 61 65, 1996

Anonymous, Agri., Statistics of Pakistan. Ministry of Food and Agri. Pakistan, 2001

Bull, J. K., M. Cooper, I. H. Delacy, K. E. Bassford and D. R. Woodruff, Utility of repeated checks for hierarchical classification of data from plant breeding trials. Field Crop Res., 30: 79 95, 1992

Eberhart, S. and W. A. Russel, Stability Parameters for comparing varieties. Crop Sci., 6: 3640 1966

Malik, I. A., G. Sarwar and Y. Ali, Genetic studies in mungbean (Vigna Radiata (L) Wilczek). In heritance of tolerance to mungbean mosaic virus and some morphological characters. Pak. J. Bot. 18 (2): 189-198, 1986

Matus, A., A. E. Slinkard and C. V. Kessel, Genotype $x$ environment interaction for carbon isotope discrimination in spring wheat. Crop Sci. 37: 97 102, 1997

Romagosa, I., S. E. Ullrich, F. Han and P. M. Hayes, Use of the additive main effects and multiplicative interactions in QTL mapping for adaptation in barley. Theor. Appl. Genet., 93 3037, 1996

Steel, R. G. D., and J. H. Torrie, Principles and procedures of Statistics. McGraw Hill Book Company, Inc. New York, 1980 

